Open Access

\title{
Upper arm circumference development in Chinese children and adolescents: a pooled analysis
}

Fang Tong ${ }^{1 *}$ and Tong $\mathrm{Fu}^{2}$

\begin{abstract}
Background: Upper arm development in children is different in different ethnic groups. There have been few reports on upper arm circumference (UAC) at different stages of development in children and adolescents in China. The purpose of this study was to provide a reference for growth with weighted assessment of the overall level of development.
\end{abstract}

Methods: Using a pooled analysis, an authoritative journal database search and reports of UAC, we created a new database on developmental measures in children. In conducting a weighted analysis, we compared reference values for 0 60 months of development according to the World Health Organization (WHO) statistics considering gender and nationality and used $Z$ values as interval values for the second sampling to obtain an exponential smooth curve to analyze the mean, standard deviation, and sites of attachment.

Results: Ten articles were included in the pooled analysis, and these articles included participants from different areas of China. The point of intersection with the WHO curve was 3.5 years with higher values at earlier ages and lower values at older ages. Boys curve was steeper after puberty. The curves in the studies had a merged line compatible. The $Z$ values of exponential smoothing showed the curves were similar for body weight and had a right normal distribution.

Conclusions: The integrated index of UAC in Chinese children and adolescents indicated slightly variations with regions. Exponential curve smoothing was suitable for assessment at different developmental stages.

Keywords: Upper arm circumference, Chinese children and adolescents, Pooled analysis

\section{Introduction}

Upper arm circumference (UAC) assessment reflects comprehensive growth in children, such as growth of skeleton, muscles, and subcutaneous fat, which has been used as an alternative indicator of nutritional status if collection of height and weight measurements was difficult. Previous Chinese reports have concentrated on assessment during the 2000s, and these reports mainly focused on malnutrition in children [1].

There are some differences in UAC among different racial or ethnic groups: the general population and athletes or people who do physical labor for a living. Adult

\footnotetext{
* Correspondence: tongfang371@163.com

${ }^{1}$ The Capital Institute of Pediatrics, Room 415, Science Building, No.2 Ya Bao Road, Beijing 100020, People's Republic of China

Full list of author information is available at the end of the article
}

muscle strength in the African, European, and Asian populations are different, with Asians being slightly inferior in terms of UAC. There are also some differences among ethnic groups. According to the anthropological human body physique study performed by the Chinese National Natural Foundation [2-5], clustering analysis showed that the male Han Chinese urban and rural area populations in Jiangsu, Uzbeks, Russians, Kazaks, and 10 other northern ethnic groups had a UAC that was about $28 \mathrm{~cm}$, which would be considered as medium dimensions. The average mean of other groups were 30 to $24 \mathrm{~cm}$ for the highest to lowest UAC. Women had a lower average about $2 \mathrm{~cm}$ both medial and other groups.

Although there are these differences in adults, as well as the uncertainty of muscle development rates in

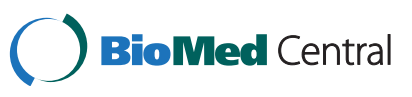

(c) 2015 Tong and Fu. This is an Open Access article distributed under the terms of the Creative Commons Attribution License (http://creativecommons.org/licenses/by/4.0), which permits unrestricted use, distribution, and reproduction in any medium, provided the original work is properly credited. The Creative Commons Public Domain Dedication waiver (http:// creativecommons.org/publicdomain/zero/1.0/) applies to the data made available in this article, unless otherwise stated. 
youngsters [6], WHO study was revised UAC by age and gender from 0 to 60 months (http://www.who.int/childgrowth). A pooled analysis of populations in Norway, Brazil, Hong Kong, and a total of seven other nationalities was carried out based on growth. Little obvious differences during the period that was studied were found, and this study is considered the representative reference.

Table 1 The 10 articles included in the pooled analysis

\begin{tabular}{|c|c|c|c|c|c|c|c|c|c|c|}
\hline Order & Sitting & $\begin{array}{l}\text { Areas of } \\
\text { China }\end{array}$ & Data collection & Age(interval) & $\begin{array}{l}N \\
\text { (total) }\end{array}$ & $\begin{array}{l}N \\
\text { (boys) }\end{array}$ & $\begin{array}{l}N \\
\text { (girls) }\end{array}$ & Presentation & $\begin{array}{l}\text { Method of } \\
\text { measurements }\end{array}$ & $\begin{array}{l}\text { Relative } \\
\text { measuring }\end{array}$ \\
\hline 1 & BJ & $\begin{array}{l}\text { Capital } \\
\text { Beijing }\end{array}$ & $\begin{array}{l}\text { Cluster sampling } \\
\text { in schools and } \\
\text { kindergartens in } \\
\text { urban and } \\
\text { suburban }\end{array}$ & 3-18 years (1 year) & 19,705 & 10,151 & 9554 & $\begin{array}{l}\text { Dissertation } \\
2009\end{array}$ & $\begin{array}{l}\text { Mid-upper } \\
\text { arm } \\
\text { circumference }\end{array}$ & Height, weight \\
\hline 2 & $\mathrm{SX}(\mathrm{U}, \mathrm{R})$ & $\begin{array}{l}\text { Yangquan } \\
\text { city of } \\
\text { Shanxi } \\
\text { province of } \\
\text { central } \\
\text { north }\end{array}$ & $\begin{array}{l}\text { Hierarchy cluster } \\
\text { sampling in } 101 \\
\text { survey sets }\end{array}$ & $\begin{array}{l}0-5 \text { years ( } 0-6 \text { months } \\
\text { ( } 1 \text { months), } 6-12 \\
\text { months ( } 2 \text { months), 1- } \\
2 \text { years ( } 3 \text { months), 3- } \\
5 \text { years ( } 6 \text { months)) }\end{array}$ & 6334 & 3262 & 3072 & Pan 2011 & $\begin{array}{l}\text { Mid-upper } \\
\text { arm } \\
\text { circumference }\end{array}$ & $\begin{array}{l}\text { Height, weight, } \\
\text { circumference } \\
\text { of chest and } \\
\text { head }\end{array}$ \\
\hline 3 & $\mathrm{AH}$ & $\begin{array}{l}\text { Anhui } \\
\text { province of } \\
\text { central } \\
\text { south }\end{array}$ & $\begin{array}{l}\text { Random cluster } \\
\text { sampling in } 3 \\
\text { elementary } \\
\text { schools and } 2 \\
\text { junior high } \\
\text { schools }\end{array}$ & $6-17$ years (2 years) & 4476 & 2275 & 2201 & Jiang 2002 & $\begin{array}{l}\text { Mid-upper } \\
\text { arm } \\
\text { circumference }\end{array}$ & $\begin{array}{l}\text { Height, weight, } \\
\text { circumference } \\
\text { of chest, triceps } \\
\text { skin-fold } \\
\text { thickness }\end{array}$ \\
\hline 4 & $S Z$ & $\begin{array}{l}\text { Suzhou city } \\
\text { in Jiangsu } \\
\text { province in } \\
\text { Yangtze } \\
\text { north }\end{array}$ & $\begin{array}{l}\text { Cluster sampling } \\
\text { in kindergartens }\end{array}$ & 3-6 years (1 years) & 1061 & 577 & 484 & Liu 1988 & $\begin{array}{l}\text { Mid-upper } \\
\text { arm } \\
\text { circumference }\end{array}$ & Height, weight \\
\hline 5 & ZJ & $\begin{array}{l}\text { Zhejiang } \\
\text { province in } \\
\text { Yangtze } \\
\text { south }\end{array}$ & $\begin{array}{l}\text { Random } \\
\text { sampling 1- } \\
\text { 3grade in } 16 \\
\text { elementary } \\
\text { schools }\end{array}$ & 6-10 years (1 years) & 1515 & 843 & 672 & Tan 2004 & $\begin{array}{l}\text { Mid-upper } \\
\text { arm } \\
\text { circumference }\end{array}$ & Height, weight \\
\hline 6 & $\mathrm{IM}$ & $\begin{array}{l}\text { Hohhot city } \\
\text { of Inner } \\
\text { Mongolia of } \\
\text { Northwest }\end{array}$ & $\begin{array}{l}\text { Random } \\
\text { sampling in } 10 \\
\text { kindergartens }\end{array}$ & $3-7$ years (6 months) & 3662 & 1936 & 1726 & $\begin{array}{l}\text { Wuyunrle } \\
2000\end{array}$ & $\begin{array}{l}\text { Mid-upper } \\
\text { arm } \\
\text { circumference }\end{array}$ & $\begin{array}{l}\text { Nine } \\
\text { circumferences } \\
\text { of chest, head, } \\
\text { waist, and so } \\
\text { on }\end{array}$ \\
\hline 7 & LN & $\begin{array}{l}\text { Dalian city } \\
\text { of Liaoning } \\
\text { province of } \\
\text { Northeast }\end{array}$ & $\begin{array}{l}\text { Random } \\
\text { sampling }\end{array}$ & 7-17 years (1 years) & 1203 & 594 & 609 & Xu 2000 & $\begin{array}{l}\text { Mid-upper } \\
\text { arm } \\
\text { circumference } \\
\text { in Shao's } \\
\text { version }\end{array}$ & $\begin{array}{l}\text { Four } \\
\text { circumferences } \\
\text { of chest, hip, } \\
\text { minimum- } \\
\text { waist, } \\
\text { maximum-leg }\end{array}$ \\
\hline 8 & GX(Miao) & $\begin{array}{l}\text { Miao } \\
\text { nationality } \\
\text { in Guangxi } \\
\text { municipality } \\
\text { in } \\
\text { Southwest }\end{array}$ & $\begin{array}{l}\text { Miao nationality } \\
\text { sampling }\end{array}$ & 8-16 years (1 years) & 814 & 454 & 360 & Huang 2005 & $\begin{array}{l}\text { Mid-upper } \\
\text { arm } \\
\text { circumference } \\
\text { in Wu } \\
\text { Rukang's } \\
\text { version }\end{array}$ & $\begin{array}{l}\text { Height, weight, } \\
\text { skin-fold thick- } \\
\text { ness, body fat }\end{array}$ \\
\hline 9 & GX(Zhuang) & $\begin{array}{l}\text { Zhuang } \\
\text { nationality } \\
\text { municipality } \\
\text { of Guangxi } \\
\text { of } \\
\text { Southwest }\end{array}$ & $\begin{array}{l}\text { Random } \\
\text { sampling in } 21 \\
\text { schools in } 4 \\
\text { counties in } 2 \\
\text { cities }\end{array}$ & 7-18 years (1 years) & 12,339 & 6825 & 5514 & Tan 1994 & $\begin{array}{l}\text { Mid-upper } \\
\text { arm } \\
\text { circumference }\end{array}$ & Height, weight \\
\hline 10 & GD & $\begin{array}{l}\text { Guangzhou } \\
\text { city of } \\
\text { Guangdong } \\
\text { province of } \\
\text { Southeast }\end{array}$ & $\begin{array}{l}2 \text { hierarchy } \\
\text { cluster sampling } \\
\text { in } 10 \\
\text { kindergartens }\end{array}$ & 4-8 years (1 years) & 9108 & 4780 & 4328 & Su 2003 & $\begin{array}{l}\text { Mid-upper } \\
\text { arm } \\
\text { circumference }\end{array}$ & $\begin{array}{l}\text { Height, weight, } \\
\text { skin-fold } \\
\text { thickness }\end{array}$ \\
\hline
\end{tabular}


National data on children's growth and development was also published by the Chinese Public Health Ministry, and the data were mainly about height, weight, and head circumference by age and gender, but the study did not clarify UAC. Searching the published data to date, articles have mainly described results of region's survey. It is therefore necessary to carry out a pooled analysis to determine the UAC growth conditions of children and adolescents in Chinese population, which is one fourth of the world's population.

\section{Methods}

\section{Data sources}

A search was carried out for articles published in journals such as the Wanfangdata and Tsinghua-Tongfang using the keywords "upper arm circumference" to identify published or dissertations on UAC measurements. Hundreds of articles were considered, and ten of them included measurement values for UAC. The articles included participants in various regions of China, which involved Capital Beijing and central, northeast, southeast, northwest, and southwest provinces and cities in China. The UAC measurements in these articles were all the same to the pediatric measuring method generally used as the attachment of halfway point of the acromion to olecranon as a measurement point. Age groups in the studies varied (Table 1). Data were extracted and entered into an Excel database and were then analyzed with SPSS16.

\section{Data processing}

UAC data were summarized and weighted by age and gender. $Z$ values were calculated and the mean and standard deviations were determined. Weighted smoothing of the curves was carried out after the means were connected. According to age and gender, the median average was $Z=0(Z>=-1$ and $Z<=1) ; Z=-1(Z<-1$ and $Z>=-2) ; Z=-2(Z>-2$ and $Z<=-3) ; Z=-3(Z>$ -3 and $Z>=-4) ; Z=1(Z>1$ and $Z<=2) ; Z=2(Z>2$ and $Z<=3)$; and $Z=3(Z>3$ and $Z<=4)$. To calculate the mean and standard deviation with the $Z$ value intervals, we obtained a smooth curve with exponential smoothing.

\section{Data analysis}

The Chinese weighted values and the WHO data released online in 2006 (0- to 60-month-old children) were analyzed. Data, those compared and merged with growth curves by gender, were included. The $Z$ values and exponential smoothing curve points were determined.

\section{Results}

\section{Multicenter data distribution}

Ten articles were included in the pooled analysis and participants from the northeast (DL), northwest (IM), southeast (GD), southwest (GX), the central plains (SX), central south (AH), and southwest (GD), and Yangtze areas (SZ and ZJ) of China, as well as Capital Beijing. The data on central Yangquan, Shanxi province, covered ages from 0 months to 4.5 years old and included both urban and rural children. Other multicenter reports based on a wide geographic distribution were representative of the general population and covered children who were $0 \sim 18$ years old (Table 1) [7-15].

\section{Weighted comparison with the WHO study by gender}

By gender, the weighted mean compared with the WHO study had a similar cross point at 3.5 years old. Differences with the WHO study were not obvious for boys and girls (Figs. 1 and 2).

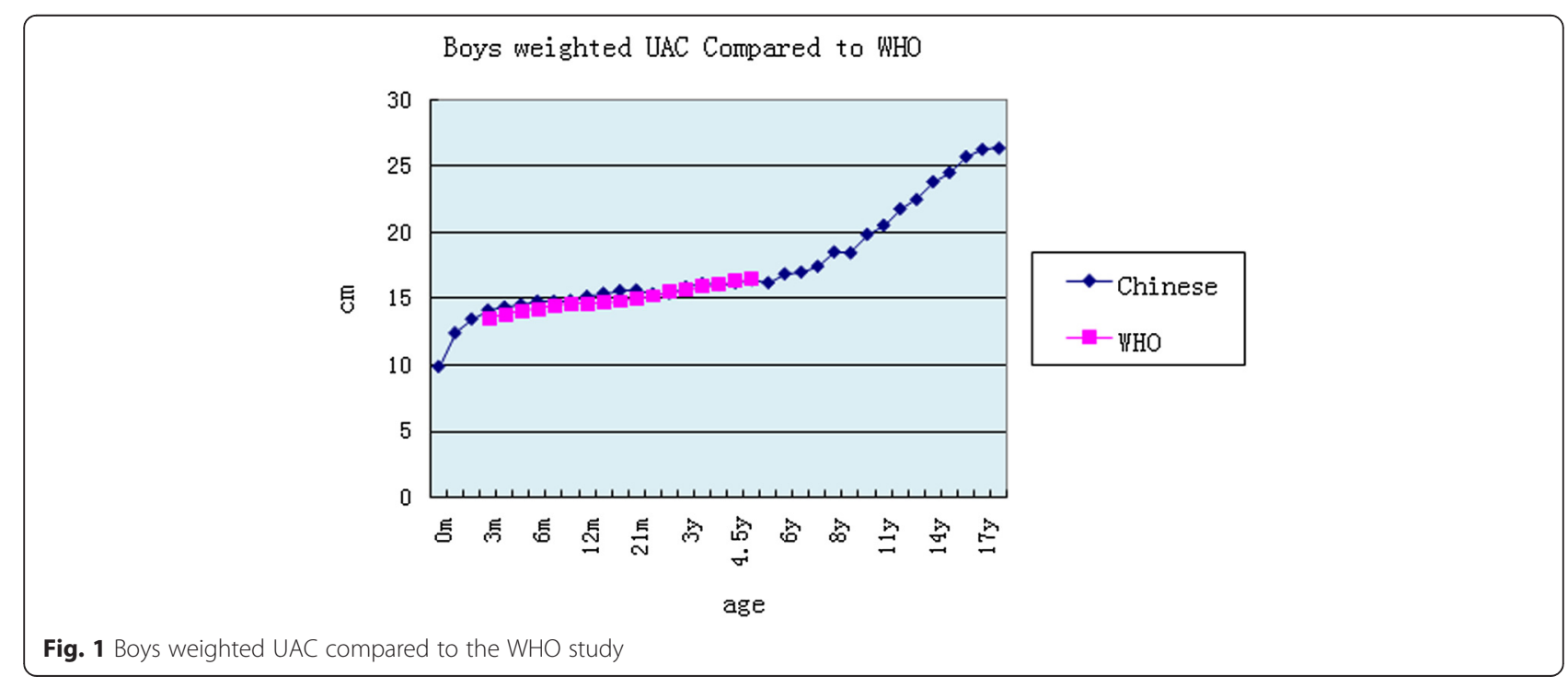




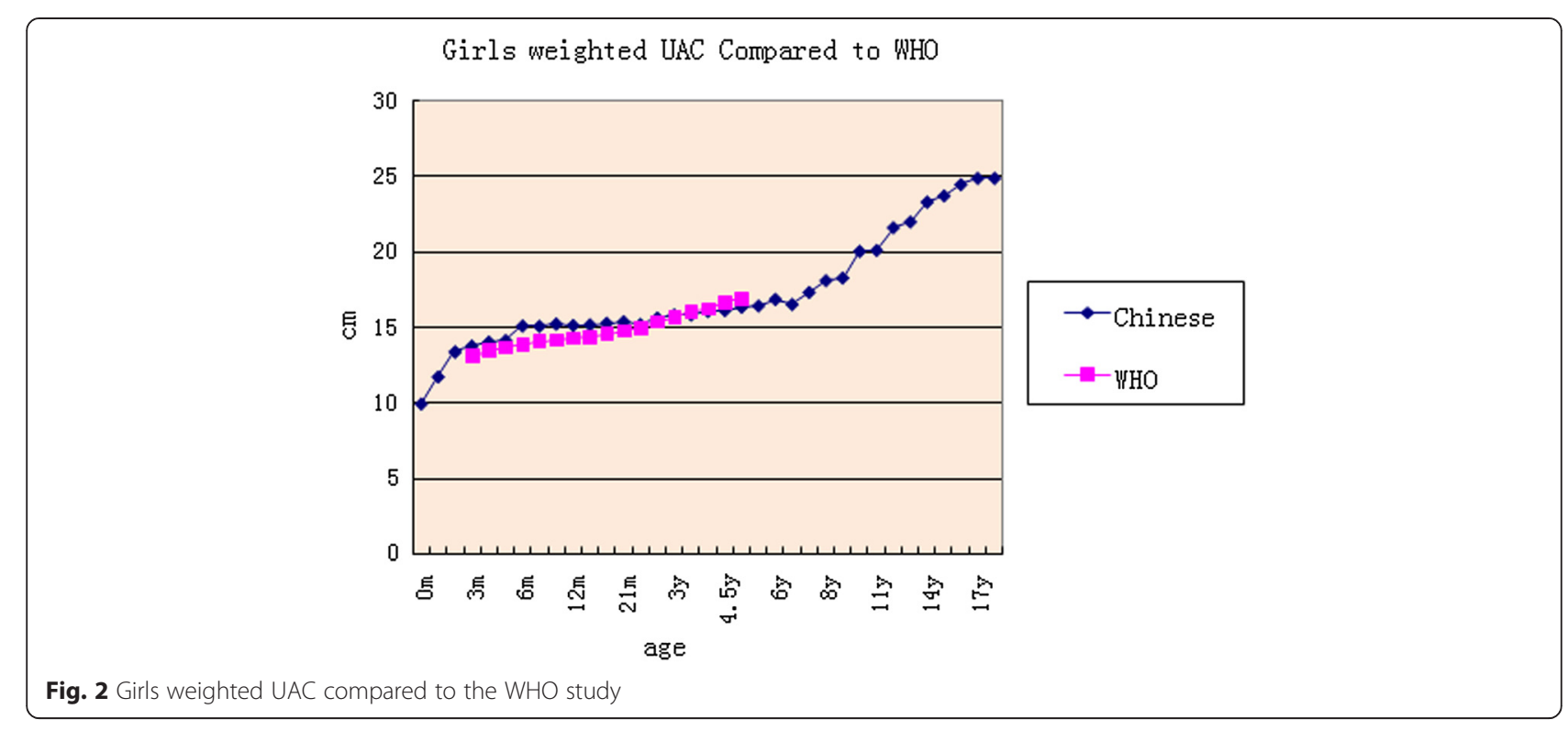

UAC weighted curves comparisons by gender

There were subtle differences in gender before puberty and more differences after puberty. The curve for boys was steeper (Fig. 3). Within each UAC curve chart, age groups cross-covered each other. The weighted curve integrated the studies smoothly, which had the possibility to add the $Z$ score loci on it excluding 0-2 years (Figs. 4 and 5).

\section{Curve smoothing}

The pooled analysis of the studies from the literature showed some regularities in $Z$ scores for each locus, with boys and girls showing similar variation. After puberty, the values for boys were higher than for girls in the exponential smoothed curve (Table 2 and Figs. 6 and 7).

\section{Discussion}

\section{Comparison with the WHO study}

The age phases of the pooled analysis were broad; 0 to 60 months range was compared in the WHO study [6]. In our study, the weighted age boundary segmentation was the following: cutoff 1 month before a half year of age, 2 months after a half year old, 3 months at 2 years

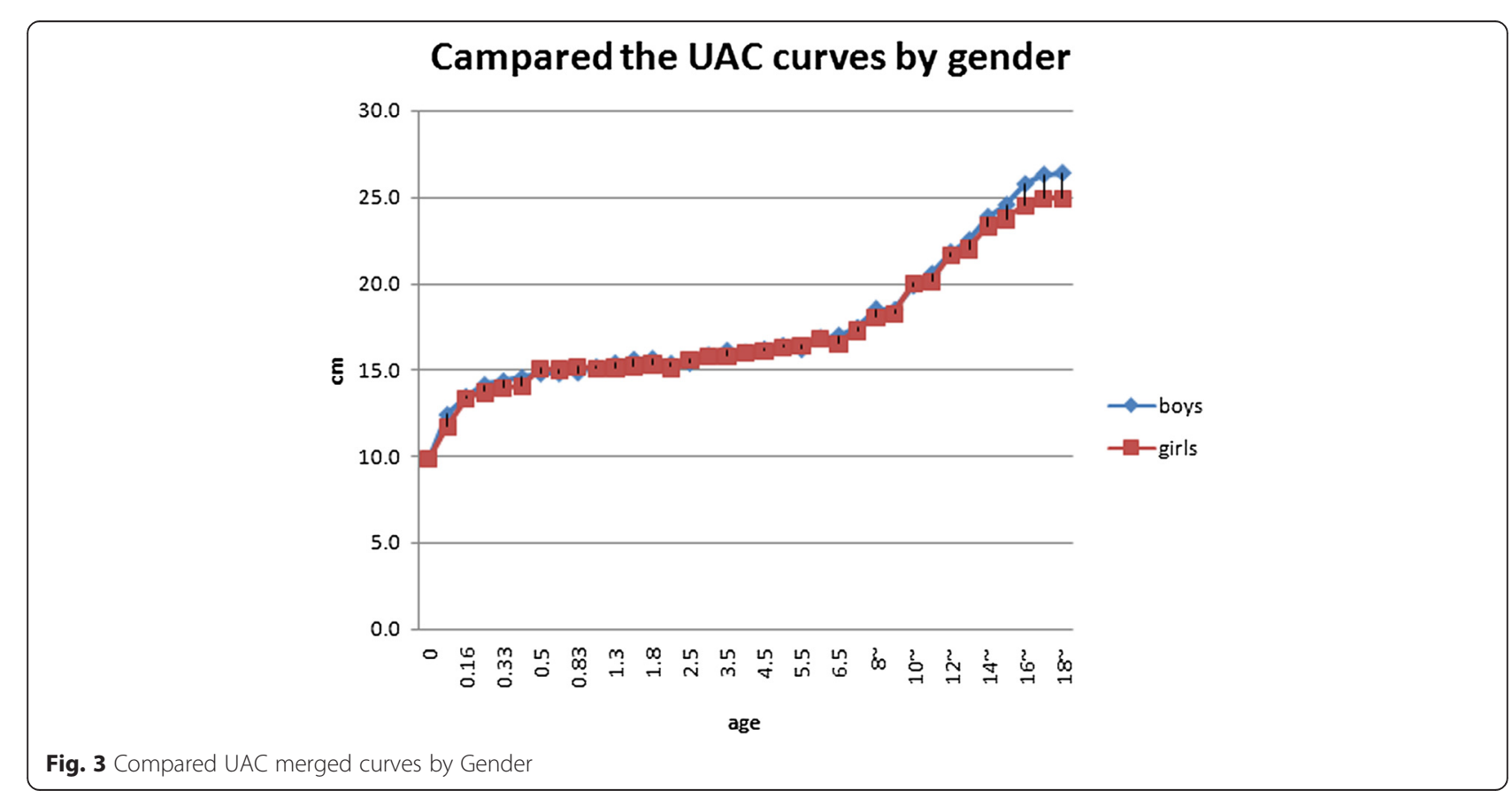




\section{UAC merged line of boys}

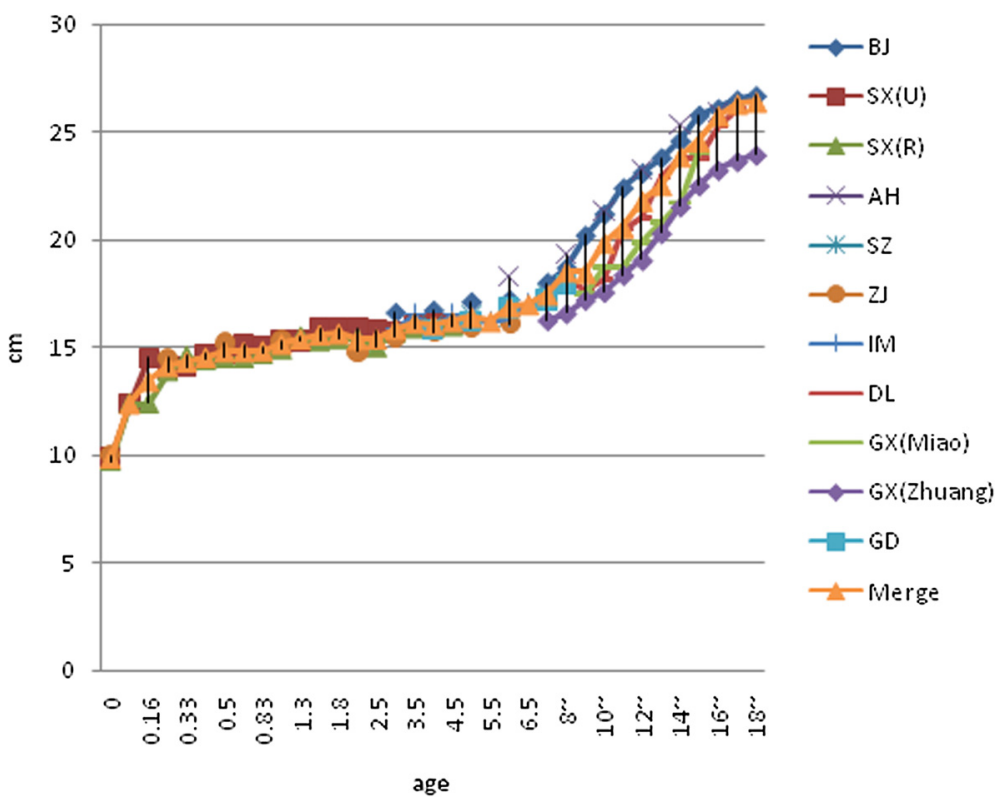

Fig. $4 \cup A C$ curves comparing with boys

old, 6 months within 2-6 years of age, and 1 year during the range 7 to 18 years old. The comparison of results showed that there was some crossover with the curve of the WHO study but with the first segment showing values that a few above and then below the WHO study curve with a node located at 3.5 years. The reason may be that the curve of WHO study was obtained with exponential smoothing (http://www.who.int/nutrition/ media_page). Many studies in the developing countries compared children's UAC to WHO references as well.

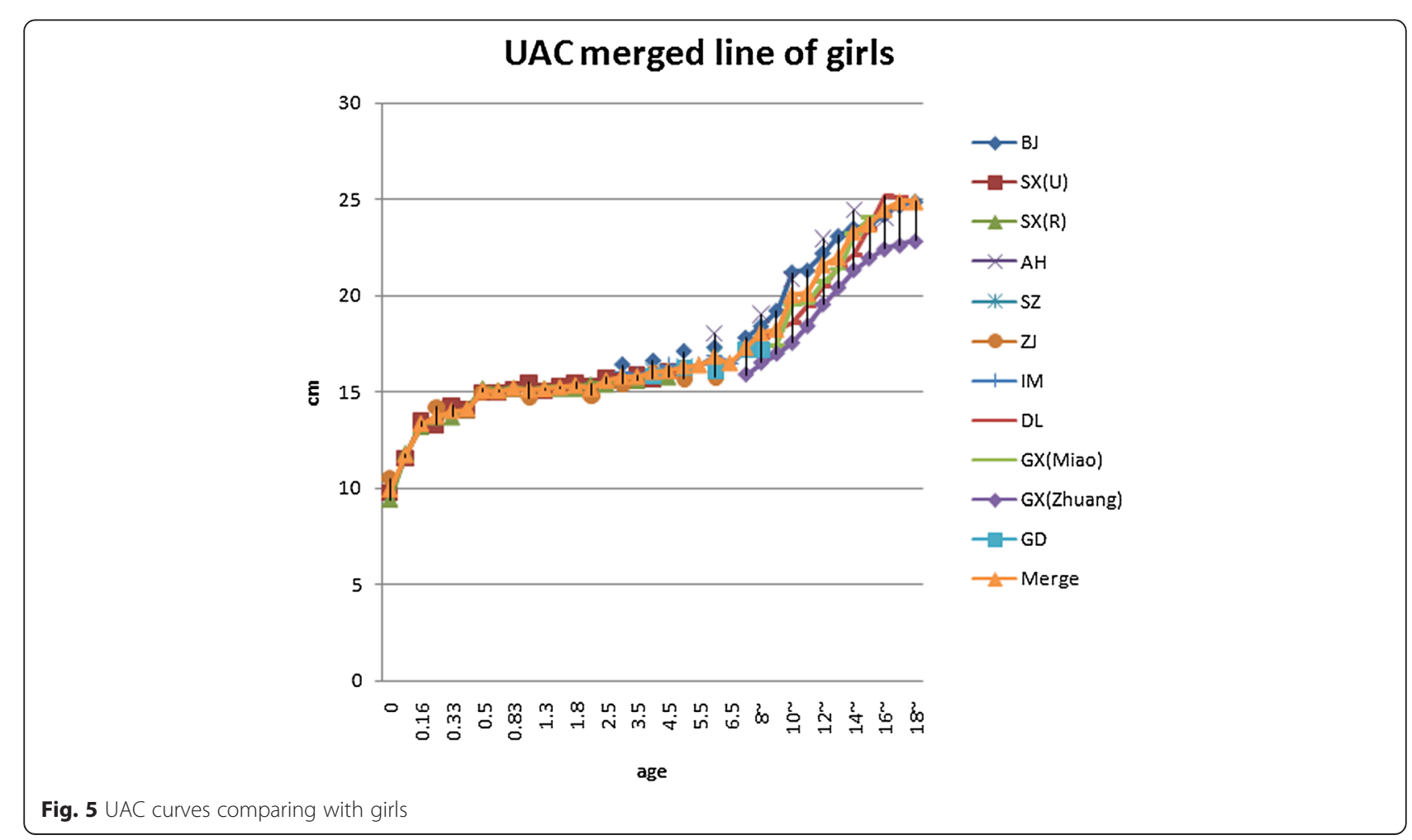


Table 2 The equations for $Z$ score loci by gender

\begin{tabular}{llll}
\hline Girls & \multicolumn{3}{l}{ Boys } \\
\hline$Y_{0}=15.508 e 0.0321 X$ & $R^{2}=0.9703$ & $Y_{0}=15.428 e 0.0361 X$ & $R^{2}=0.9637$ \\
$Y_{+3}=22.786 e 0.0349 X$ & $R^{2}=0.8277$ & $Y_{+3}=23.293 e 0.0402 X$ & $R^{2}=0.8389$ \\
$Y_{+2}=20.447 e 0.0341 X$ & $R^{2}=0.8883$ & $Y_{+2}=21.089 e 0.0384 X$ & $R^{2}=0.8704$ \\
$Y_{+1}=18.491 e 0.0332 X$ & $R^{2}=0.9263$ & $Y_{+1}=18.777 e 0.0383 X$ & $R^{2}=0.8965$ \\
$Y_{-1}=13.458 e 0.0294 X$ & $R^{2}=0.9563$ & $Y_{-1}=13.235 e 0.0337 X$ & $R^{2}=0.8437$ \\
$Y_{-2}=12.724 e 0.0235 X$ & $R^{2}=0.9178$ & $Y_{-2}=11.136 e 0.0337 X$ & $R^{2}=0.8546$ \\
\hline
\end{tabular}

Reports have shown that a ROC curve can be used for evaluation of malnutrition in children under the age of five and UAC by age has better sensitivity than height in Kenya, Africa [16]. There were $26.8 \%$ of children below 2 standard deviations from the mean in a study on children in Malaysia, Asia [17]. Nevertheless, some results implied that the use of the international reference may lead to lower specificity and predictive value in the screening of malnourished children in developing countries such as Uganda [18]. The average of children under 5 years old was at -2 standard deviations from the mean in a study carried out in Kenya [19]. Therefore, that seems to need a local UAC curve for references.

\section{Chinese children UAC curves integration}

There were significant differences in adult UAC in China, because China is a large region and includes many nationalities. The Male Xinjiang Khalkhas, Tatar, and Xibo populations had a UAC of about $30 \mathrm{~cm}$, which would be considered as brawnier. Ten southern ethnic groups, i.e., Hainan Han, Hui, Miao, DuLongZu, MuLaoZu, Buyi, Uighur, Tu, Mongolian, and Li had a UAC of about $24 \sim 25 \mathrm{~cm}$, which would be considered as smaller. Women were divided into four types, and the strongest groups, in addition to the three of the male groups and ethnic Russians, had a UAC of about $28 \mathrm{~cm}$. The Han, Uzbek, and Kazak urban and rural area populations in Jiangsu had a UAC of about $26 \mathrm{~cm}$. Uely had a below average UAC of about 23 24 cm. The Hui, Soil, and Mongolian populations had a UAC of about $22 \sim 23 \mathrm{~cm}$, which would be considered as thin $[2-5,20]$. Asian children had less UAC than Caucasians [21]. In the present study, Children UAC development showed some differences in different regions, but the mean gaps between the values of highest and lowest curve of each age groups were all less than the standard deviation of their own study, although those were narrow before puberty and wider in adolescence (Figs. 4 and 5). The charts of the curves showed the merged curve was feasible made by combined studies, and the ligature of weighted mean UAC of age phases is also thought as the mean value of the reference curve. The $Z$ score values could be added as well.

\section{Growth curve for each $Z$ score}

Many studies have supported the superiority of $Z$ scores for UAC by age. Use of UAC with age- and sex- adjusted $Z$ scores gave a better sensitivity than absolute cut of values in the identification of children wasting (acute undernutrition) [22-24]. Furthermore, regarding preschool

\section{UAC Pool-analysis on boys}

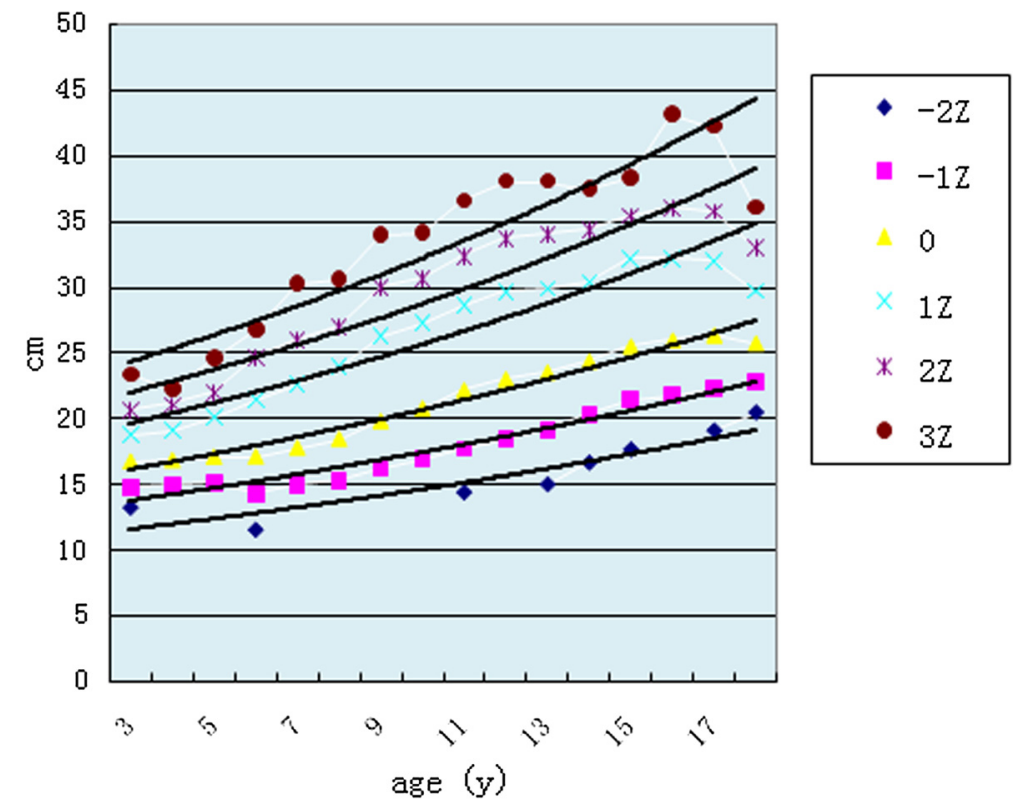

Fig. 6 Pooled analysis for boys 


\section{UAC Pool-analysis on girls}

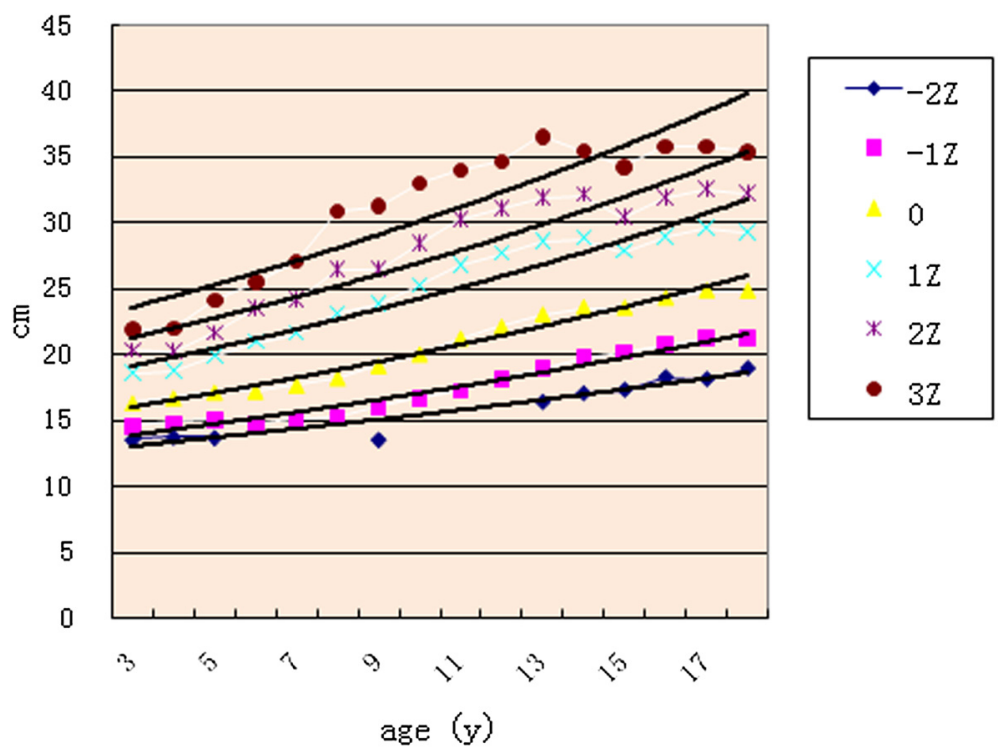

Fig. 7 Pooled analysis for girls

obesity screening, the $Z$ score of UAC by age seemed to be an appropriate alternative, which was better than UAC by height [25]. In addition, $Z$ scores for other anthropometric indicators such as weight have showed symmetry if cut small in the right tail with $Z$ score analysis [26]. UAC $Z$ scores in this pooled analysis showed a normal distribution, similar to the curve for weight, which was a $-2 \sim+3$ right normal curve. The index-smoothing trend showed some regularities with directions going up and down through various points in each $\mathrm{Z}$ trend. The development chart can be a representative reference for Chinese children and adolescents.

\section{Conclusion}

The pooled analysis on UAC data for Chinese children and adolescents had a broad weighted value. The age group 0 60 months compared with the WHO curve showed there was some crossover with a little higher values for children younger than 3.5 years old and lower values for children older than 3.5 years old. $Z$ scores ranged from -2 to $\sim 3$ and formed a normal distribution. Exponential smoothing was suitable for assessment.

The research has been approved by Ethics Committee of the Capital Institute of Pediatrics, within which the work was undertaken and that it conforms to the provisions of the Declaration of Helsinki.

\section{Abbreviations}

UAC: mid-upper arm circumference; ROC: receiver operating characteristic curve; WHO: Would Health Organization; CDC: Center for Disease Control and Prevention.
Competing interests

The authors declare that they have no competing interests.

\section{Authors' contributions}

This paper was conceived, designed, and written by FT. FT and TF analyzed the data. TF contributed analysis tools. Both authors read and approved the final manuscript.

\section{Acknowledgements}

We thank Professor Lianbin Zheng, from Tianjin Normal University, who gave the good suggestions. We also thank Professor Ting Zhang, and Long Li from the Capital Institute of Beijing, China, who partly supported this article publication. This research received no specific grant from any funding agency in the public, commercial, or not-for-profit sectors.

\section{Author details}

${ }^{1}$ The Capital Institute of Pediatrics, Room 415, Science Building, No.2 Ya Bao Road, Beijing 100020, People's Republic of China. Beijing Information Science and Technology University, Beijing, China.

Received: 6 February 2015 Accepted: 15 May 2015

Published online: 30 May 2015

\section{References}

1. Duggan MB. Anthropometry as a tool for measuring malnutrition: impact of the new WHO growth standards and reference. Ann Trop Paediatr. 2010;30(1):1-17.

2. Zhang XR, Zheng LB, Yu KL, Xue H, Wang Y, Rong WG, et al. Circumference and its variation with age of Jiangsu Han nationality adults. J Tianjin Normal Univ (Nature Science Edition). 2011;31(4):74-81.

3. Xu BS, Zheng LB, Lu SH, Luo DM. The circumfenrence and its variation with Age changes of the adults of dulong nationality. J Tianjin Normal Univ (Nature Science Edition). 2008;28(1):19-25.

4. Xie B, Lu SH, Zheng LB, Suo LY. Analysis of bodily circumference characteristics of Russ adults in inner Mongolia. Chin J Anatomy. 2007;30(4):483-7.

5. Li SY, Zheng LB. The variation of circumference values of Uzbek adults. J Tianjin Normal Univ. 2006;26(3):15-20.

6. Onis MD, Yip R, Mei Z. The development of MUAC-for-age reference data recommended by a WHO Expert Committee. Bull World Health Organ. 1997;75(1):11-8. 
7. Xu F, Zhao W, Ma XK. Study on development of body growth of Dalian Han nationality students. Chin J Anatomy. 2000;23(5):479-82.

8. Huang XF, Li LZ, Wu YY, Wei QJ, Li ZHH. Study on skinfold of Guangxi Miao nationality students. Anat Res. 2005;27(2):141-3.

9. SuYX XXC. Evaluation of growth and development status of children aged 4-8 years in Guangzhou city. Chin J School Health Dec. 2003;24(6):598-9.

10. Jiang JH, Zhang JX, Gao YQ, Liu JP, Gao M. Growth indexes building of 6-17 children reference in Hefei city. Acta Univ Med. 2002;37(1):65-6.

11. Wuyungerle D, Temuqiletu G, Jin YC. Studies on present growth of 10 body parts circumference of children aged from 3 to 7 in huhhot. J Inner-Mongolia Normal Univ (Nature Science Edition). 2000;29(3):229-33.

12. Pan YQ, Li HY, Song ZHH, Li ZHY, Duan SHH, Ge JJ, et al. Study of growth and nutritional status of children aged $0-5$ year in Yangquan city. Chin J Woman Child Health Res. 2011;22(6):723-7.

13. TanY ZJK, Ding BG, Liu HJ, Chang J, Fan DM. Assessment of children nutritional status with upper-arm circumference for height. Chin J Public Health Dec. 2004;20(12):1456-7.

14. Tan ChM LBH, Huang JP, Lu MY, Chen HH. To probe assessing the nutrition statues of the children and adolescent with upper-arm circumference. Chin J School Health. 1994;15(5):331-2.

15. Liu LM, Gu YM, Gu JZH, Bai HY, Zhang HS. To probe the nutrition statues of the preschool children with upper-arm circumference. Chinese academic J. Suzhou Med Univ. 1988;8(2):118-20.

16. Mei Z, Grummer-Strawn LM, de Onis M, Yip R. The development of a MUAC-for-height reference, including a comparison to other nutritional status screening indicators. Bull World Health Organ. 1997;75(04):333-41.

17. Cheah WL, Wan Muda WA, Mohd Hussin ZA, Thon CC. Factors associated with undernutrition among children in a rural district of Kelantan, Malaysia. Asia-Pacific J Public Health Asia-Pacific Acad Consortium Public Health. 2010;XX(X):1-13.

18. Cortinovis I, Vella V, Ndiku N, Milani S. Weight, height and arm circumference of children under 5 in the district of Mbarara, south-west Uganda. Ann Hum Biol. 1997;24(6):557-68.

19. Vonk R. Growth of under five-year-old children in Kyeni, Kenya. Trop Geogr Med. 1993:45(4):175-8.

20. Xuehereti L, Polat $Y$. An investigation of the subcutaneous fat thickness of Uygur, Kazak, Han and Hui children in Urumqi city. J Xinjiang Med Univ. 2003;26(3):265-9.

21. Yu S, Huang ZJ, Singh CK. Health status and health services utilization among US Chinese, Asian Indian, Filipino, and other Asian/Pacific Islander children. Pediatrics. 2004;113(1):101-7.

22. Gernaat HB, Dechering WH, Voorhoeve HW. Absolute values or Z scores of mid-upper arm circumference to identify wasting? Evaluation in a community as well as a clinical sample of under fives from Nchelenge, Zambia. J Trop Pediatr. 1996;42(1):27-33.

23. Gewa CA, Oguttu M, Yandell NS. Maternal nutrition in rural Kenya: health and socio-demographic determinants and its association with child nutrition. Maternal Child Nutr. 2011;5:1-12.

24. Ghosh A, Dutta R, Sarkar A. Heritability estimation of conventional cardiovascular disease risk factors in Asian Indian families: The Calcutta family study. Indian J Hum Gene. 2010;16(01):28-32.

25. de Almeida CA, Del Ciampo LA, Ricco RG, Silva SM, Naves RB, Pina JF. Assessment of mid-upper arm circumference as a method for obesity screening in preschool children. J Pediatr. 2003;79(5):455-60.

26. Tong F, Mi J, Yan SJ, Cheng H, Hou DQ, Zhao XY. Children growth assessment with Z-score in Beijing. Chin J Children Health Care. 2007:15(4):350-3.

\section{Submit your next manuscript to BioMed Central and take full advantage of:}

- Convenient online submission

- Thorough peer review

- No space constraints or color figure charges

- Immediate publication on acceptance

- Inclusion in PubMed, CAS, Scopus and Google Scholar

- Research which is freely available for redistribution 